\title{
The lichen genera Phaeographis and Phaeographina (Graphidaceae) in Australia 3: Phaeographis - new reports and new species
}

\author{
Alan W. Archer
}

\begin{abstract}
Archer, Alan W. (Royal Botanic Gardens Sydney, Mrs Macquaries Road, Sydney NSW 2000, Australia) 2001. The lichen genera Phaeographis and Phaeographina (Graphidaceae) in Australia 3: Phaeographis - new reports and new species. Telopea 9(3): 663-677. An account is given of the lichen genus Phaeographis (Graphidaceae) in Australia, other than previously described taxa based on Australian type specimens. Nine species are described of which two are new to science and six are new reports of the genus in Australia. Phaeographis nardiensis A.W. Archer and P. tuberculifera A.W. Archer are described as new species and P. ceratoides (Vain.) Zahlbr., P. dendroides (Leight.) Müll. Arg., P. hypoglaucoides K.P. Singh \& Awasthi, P. melanostalazans (Leight.) Müll. Arg., P. subdividens (Leight.) Müll. Arg. and P. subtigrina (Vain.) Zahlbr. are reported as new to Australia. Phaeographis mucronata (Stirt.) Zahlbr. is reported as the earliest name for P. australiensis Müll. Arg. and Gymnographa medusulina Müll. Arg. is reported as a synonym of Phaeographis eludens (Stirt.) Shirley. A key to all the species in the genus found in Australia is given.
\end{abstract}

\section{Introduction}

The lichen genus Phaeographis Müll. Arg. was created by Müller (1882a) to separate species with brown locular ascospores from the genus Graphis Adans. (with hyaline locular ascospores). Australian species in the genus Phaeographina (with brown muriform ascospores) have been described elsewhere (Archer 2000; 2001a; 2001c).

The recent Checklist of Australian lichens (Filson 1996) lists 17 species in the genus Phaeographis, of which 12 are based on Australian type material; a recent revision of these species found six of them to be synonymous with other species (Archer 2000). Two additional Australian Phaeographis species, P. necopinata A.W. Archer \& Elix (with hypostictic acid) and P. nornotatica A.W. Archer and Elix (with nornotatic acid) have recently been described (Archer \& Elix 1999) and an additional eight species found in Australia are described here, two of which are new to science.

This research was funded through the NSW Biodiversity Strategy

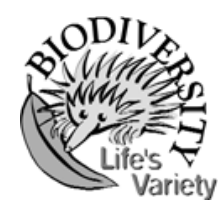




\section{Material and methods}

This account is based on the examination of type and other specimens from $\mathrm{B}, \mathrm{BM}$, BRI, GLAM, G, GZU, H, MEL, NSW, TUR, W, WELT and, in particular, the recent collections made by J.A. Elix, H. Streimann and D. Verdon (CANB), and Tasmanian collections made by $\mathrm{G}$. Kantvilas (HO). In addition, specimens from the private herbarium of H.T. Lumbsch (Essen) were examined. The techniques used follow those described previously (Archer 1999, 2000).

\section{Key to the lichen genus Phaeographis in Australia}

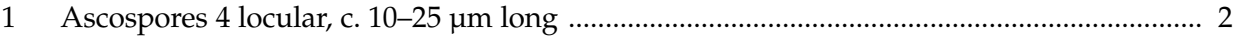

1* Ascospores > 4 locular, c. 20-40 $\mu \mathrm{m}$ long ......................................................................... 9

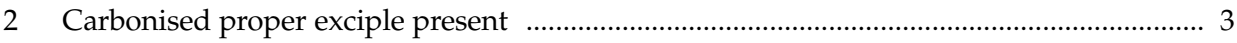

2* Carbonised proper exciple absent ..................................................................................... 5

3 Proper exciple completely carbonised, thin; ascospores 15-22 um long ................ P. elaeina

$3^{*}$ Proper exciple laterally or apically carbonised 4

4 Proper exciple laterally carbonised; ascospores 14-24 $\mu \mathrm{m}$ long

P. subintricata

$4^{*} \quad$ Proper exciple apically carbonised; ascospores 17-20 $\mu \mathrm{m}$ long

5 Thallus saxicolous; lichen compounds absent 6 Thallus corticolous; lichen compounds present or absent

6 Lirellae open; disc visible

P. hypoglaucoides

$6^{*} \quad$ Lirellae closed or only slightly open; disc not visible 7

7 Thallus smooth; thalline margin absent; ascospores 12-15 $\mu \mathrm{m}$ long P. eludens

$7^{*}$ Thallus tuberculate; thalline margin conspicuous; ascospores 10-12 $\mu \mathrm{m}$ long

8 Ascospores (8-)10-12 $\mu \mathrm{m}$ long; lichen compounds absent P. tuberculifera

8* Ascospores 18-25 $\mu \mathrm{m}$ long; norstictic acid present

9 Lirellae closed; ascospores 30-40 $\mu \mathrm{m}$ long, 8-10 locular; norstictic acid present

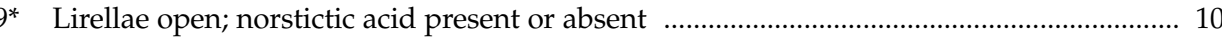

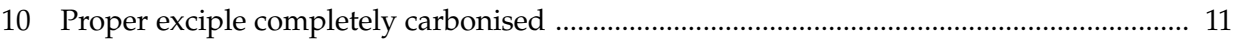

10* Proper exciple absent or brown to dark brown ................................................................. 14

11 Base thickness of proper exciple $\geq$ height of hymenium .......................................................12

$11^{*}$ Base thickness of proper exciple $<$ height of hymenium ......................................................13

12 Ascospores 9 locular, 25-37 um long; stictic acid present; exciple widening towards substrate

12* Ascospores 6-8 locular, 21-35 $\mu \mathrm{m}$ long; nornotatic acid present; exciple narrowing towards substrate

P. nornotatica

13 Lichen compounds absent; ascospores 6 locular, 21-33 $\mu \mathrm{m}$ long

13* Hypostictic acid present; ascospores 8 locular, 32-42 $\mu \mathrm{m}$ long

14 Proper exciple brown to dark brown; ascospores 18-22 $\mu \mathrm{m}$ long, 4-6 locular .....................................

$14^{*}$ Proper exciple absent

15 Stictic acid present; ascospores (19-)22-37 $\mu \mathrm{m}$ long, 6-8 locular.

$15^{*}$ Norstictic acid present; ascospores 26-37 $\mu \mathrm{m}$ long, 6-8 locular 


\section{Phaeographis species}

Phaeographis ceratoides (Vain.) Zahlbr. (Fig. 1a, 2a)

(Zahlbruckner 1923: 365).

Graphis ceratoides Vain.

(Vainio 1920: 227).

Type: The Philippines. Luzon, Benguet: Pauai, E.D. Merrill 6654, May 1909 (holo TURV 27517; iso FH).

Thallus off-white, thin, corticolous, surface smooth and dull; apothecia lirelliform, conspicuous, black, thin, immersed, numerous, conspicuously branched, open, with a thin, inconspicuous thalline margin, $1-5 \mathrm{~mm}$ long, $0.1-0.15(-0.2) \mathrm{mm}$ wide; proper exciple lacking; hymenium 100-125 $\mu \mathrm{m}$ tall; epithecium matt black, epruinose; ascospores 8 per ascus, irregularly 1-seriate, rounded ellipsoid, pale brown, 10-12 $\mu \mathrm{m}$ long, (3-)4 $\mu \mathrm{m}$ wide, 4-locular.

Chemistry: no lichen compounds found.

Distribution: occcurs in the Philippines, Indonesia and, in Australia, in north-eastern Queensland where it is found on a variety of substrates, including Amoora, Ponteria, mangroves and palms; also on Norfolk Island.

Notes: Phaeographis ceratoides is characterised by the repeatedly branched, thin, black, immersed lirellae, the very small, 4-locular ascospores and by the absence of lichen compounds. Vainio (loc. cit.) reported the ascospores in the type specimen to be 10-11 $\times 5 \mu \mathrm{m}$. The species somewhat resembles Phaeographina exilior (Vainio) Zahlbr. but that species has a pale reddish brown epithecium and muriform ascospores.

Specimens examined: Queensland: Thompson Road, Edmonton, $9 \mathrm{~km} \mathrm{~S}$ of Cairns, Elix 17612, 17614, Jul 1984 (CANB); Newell Beach, 5 km NE of Mossman, Elix 17434, 17456, Jul 1984 (CANB); Kirrima State Forest, Cardwell Range, 24 km WNW of Cardwell, Elix 15675, Jun 1984 (CANB); Conway State Forest, 16 km ENE of Proserpine, Streimann 37406, Jun 1986 (CANB); Mossman Gorge, Daintree River National Park, 6 km W of Mossman, Streimann 45890, Dec 1990 (CANB); Annan River, Grass Tree Pocket Road, 39 km S of Cooktown, Streimann 46377, Dec 1990 (B, CANB); Iron Range National Park, Tozers Gap, 29 km SW of Cape Weymouth, Streimann 56394, Oct 1995 (B, CANB); Eungella National Park, Finch Hatton Gorge, Lumbsch 11079c, Aug 1996 (herb. Lumbsch); Wooroonooran National Park, Henrietta Creek Camping Area, Lumbsch 11113i, Aug 1996 (herb. Lumbsch); Boat Ramp, c. 2 km E of Edmonton, SE of Cairns, Lumbsch 11139i, Aug 1996 (herb. Lumbsch).

Norfolk Island: Mt Pitt Reserve, Mt Bates summit trail, Elix 18562, Dec 1984 (CANB).

Phaeographis dendroides (Leight.) Müll. Arg. (Fig. 1b, 2b)

(Müller 1882a: 336).

Platygrapha dendroides Leight.

(Leighton 1869: 179).

Graphis dendroides (Leight.) Vain.

(Vainio 1920: 221).

Type: Ceylon [Sri Lanka]. South of the Island, G.H.K. Thwaites, CL 165, no date; lecto BM (Singh \& Awasthi 1979: 102). 


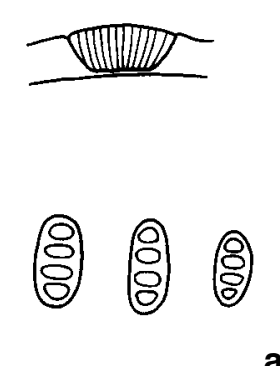

a
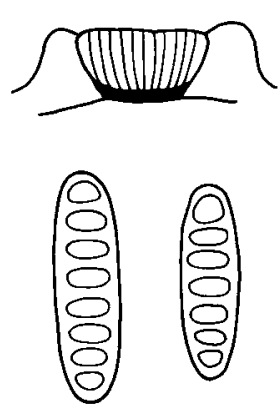
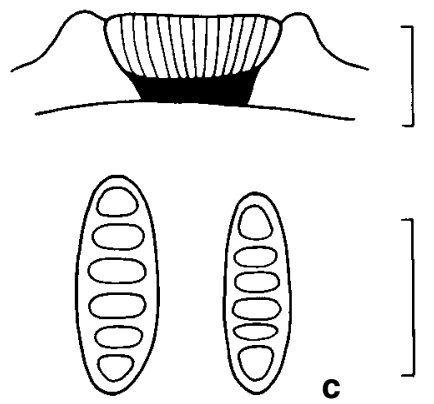

b
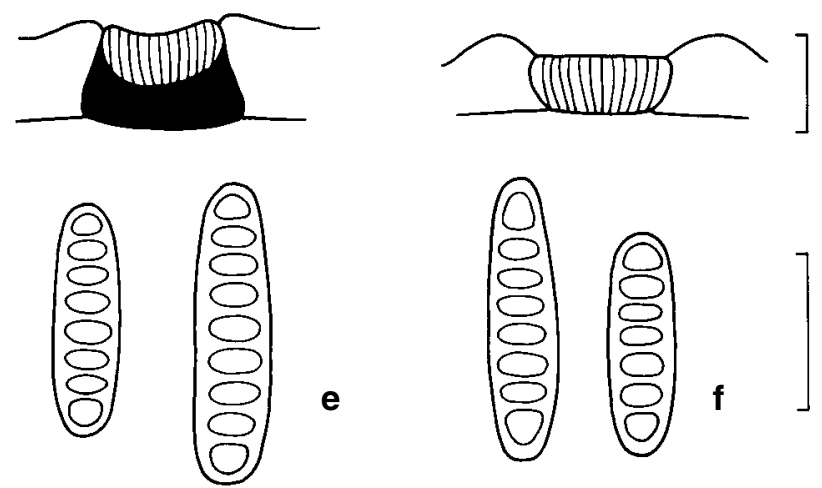
$2 \cdot \varepsilon_{200,}$
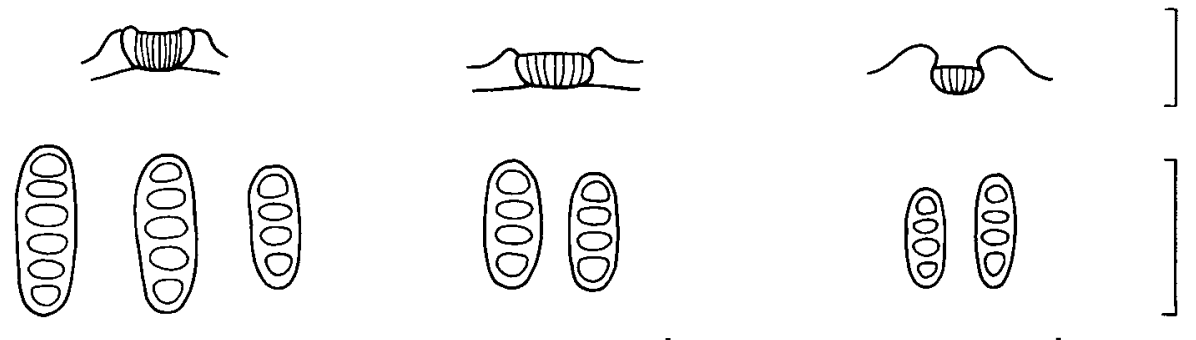

(영

h

Fig. 1. Ascospores and cross-sections of lirellae. a, Phaeographis ceratoides; b, P. dendroides; c, P. exaltata; d, P. hypoglaucoides; e, P. melanostalazans; $\mathbf{f}$, P. nardiensis; $\mathbf{g}$, P. subdividens; $\mathbf{h}$, P. subtigrina; i, $P$. tuberculifera. lirellae: scale bars $=200 \mu \mathrm{m}$; ascospores: scale bars $=20 \mu \mathrm{m}$. 


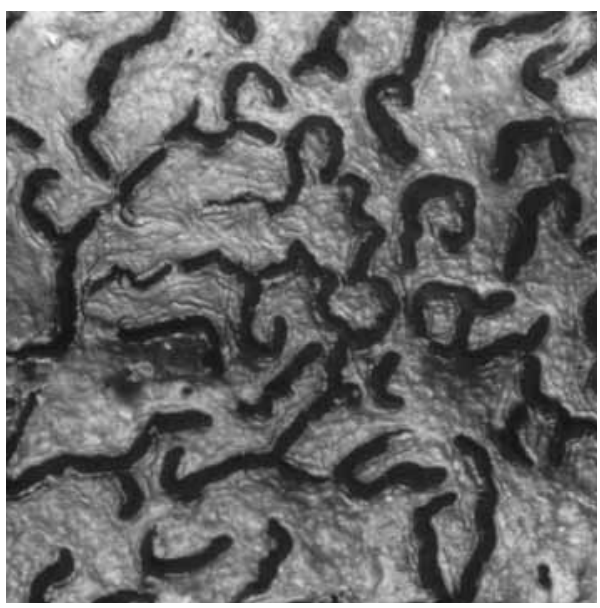

a

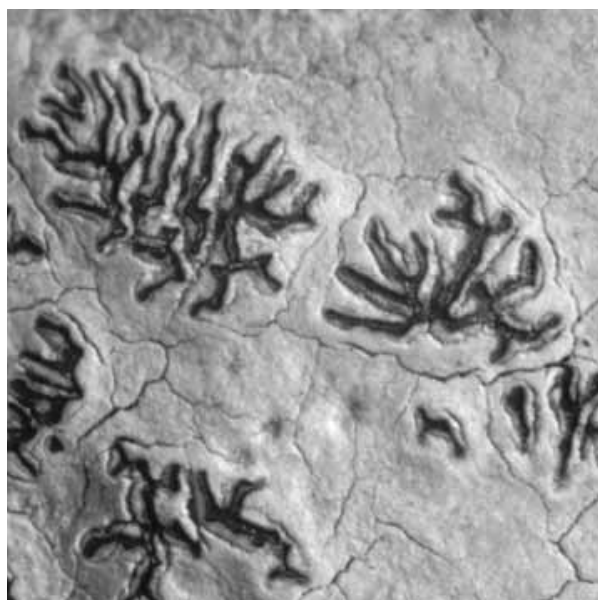

C

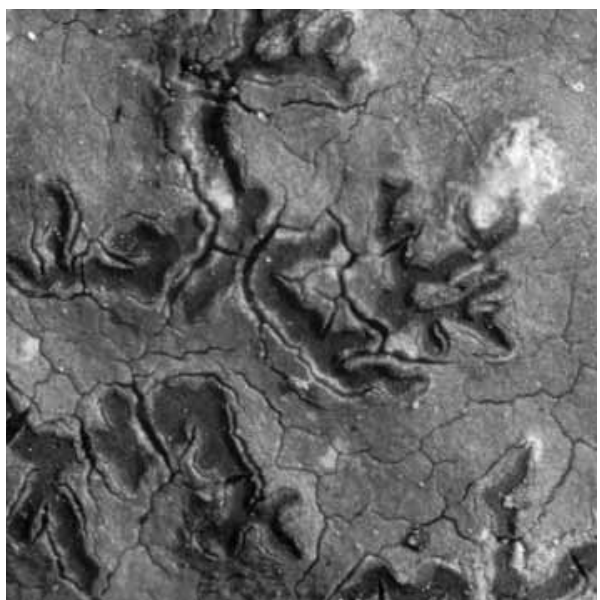

e

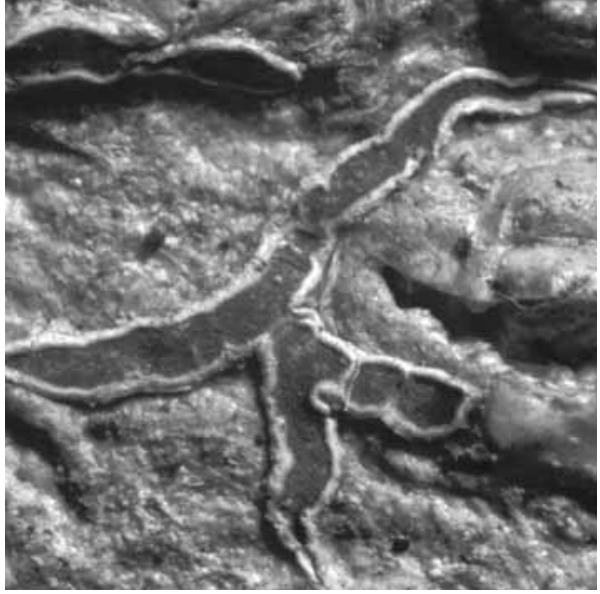

b

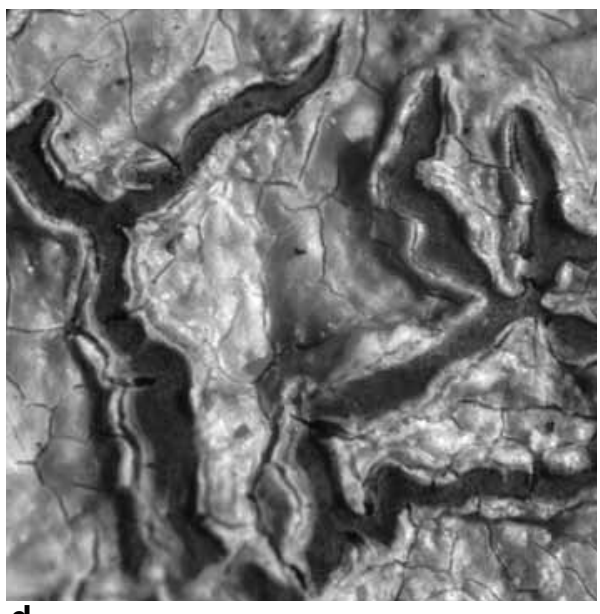

d

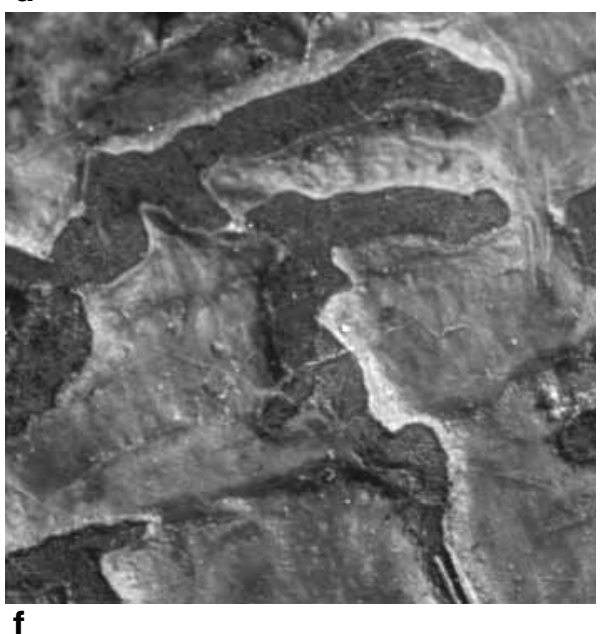

Fig. 2. a, Phaeographis ceratoides (Vain.) Zahlbr., Elix 15675 (CANB); b, Phaeographis dendroides (Leight.) Müll. Arg., Elix 16227 (CANB); c, Phaeographis eludens (Stirt.) Shirley, A. Thozet s.n. (G); d, Phaeographis exaltata (Mont. \& Bosch) Müll. Arg., Kantvilas 195/88 (NSW); e, Phaeographis hypoglaucoides Singh \& Awasthi, Elix 34516 (CANB); f, Phaeographis melanostalazans (Leight.) Müll. Arg., lectotype (BM). All $\times 17$. 
Thallus pale greenish-white, thin, corticolous, surface smooth and shiny; apothecia lirelliform, conspicuous, black, scattered or sometimes in substellate clusters, open, straight, curved or sinuous, rarely branched, sessile, with a well-defined thin, white thalline margin, 1-4 mm long, $0.3-0.5 \mathrm{~mm}$ wide; proper exciple lacking laterally, thin, black at base; hymenium (100-)125-150 $\mu \mathrm{m}$ tall; epithecium matt black, epruinose or faintly white pruinose; ascospores 8 per ascus, elongate-ellipsoid, pale brown (19-)22-37 $\mu \mathrm{m}$ long, (6-)8-10 $\mu \mathrm{m}$ wide, (5-)6-8(-9)-locular.

Chemistry: stictic acid (major) and hypostictic acid (minor-trace).

Distribution: occurs in Sri Lanka, Indonesia, Hawaiii, New Caledonia and the Philippines, and in Australia, in Queensland and New South Wales. Reported substrates in Australia include Alphitonia, Casuarina, Cryptocarya, Ficus and Pipturus.

Notes: Phaeographis dendroides is characterised by black, open lirellae, 6-8 locular ascospores and the presence of stictic acid. These features distinguish the species from the similar P. dendritica which contains norstictic acid and has larger ascospores, 30-50 $\times$ 7-10 $\mu \mathrm{m}$ (Coppins \& James 1992) cf. (19-)22-37 × (6-)8-10 $\mu \mathrm{m}$. P. dendroides is distinguished from the somewhat similar P. necopinata A.W. Archer \& Elix (Archer \& Elix 1999) by the presence of stictic acid and uncarbonised exciple, in contrast to the carbonised exciple and hypostictic acid present in P. necopinata.

Specimens examined: Queensland: Mt Baldy, 4 km SW of Atherton, Elix 16227, Jun 1984 (CANB); Herberton Road, 2 km SW of Atherton, Streimann 29173, Jun 1984 (CANB); Tully Falls Road, 8 km E of Ravenshoe, Elix 16817, Jun 1984 (CANB); Hugh Nelson Range, $15 \mathrm{~km} \mathrm{~S}$ of Atherton, Elix 16410, Jun 1984 (CANB); Main Coast Range, 14 km NNW of Mount Molloy, Elix 16956, Jun 1984 (CANB); Big Tableland, 26 km S of Cooktown, Elix 17278, Jul 1984 (CANB); Blencoe Creek, 48 km NW of Cardwell, Elix 20146, Jun 1986 (CANB).

New South Wales: track to Dangar falls, ca. 2 km N of Dorrigo, Archer G 303, Oct 1998; (NSW 456276); Cheltenham, Pennant Hills Park, ca. 20 km NW of Sydney, Archer G447, May 2000 (NSW 440793).

The Philippines: Luzon, Sorsogon: Irosin, Elmer 15055, Nov 1915 (BM); Taytay, Palawan, Merrill 9060, Apr 1913 (BM); Island of Polillo, Robinson, Bur. Sci 6999, Aug 1909 (BM).

Sri Lanka: type locality, Thwaites $C 22$, no date (BM).

Fiji: s. loc., Wilson s.n., no date (NSW 438744).

Phaeographis eludens (Stirt.) Shirley. (Fig. 2c)

(Shirley 1889: 197).

Graphis eludens Stirt.

(Stirton 1881: 72).

Type: Queensland: s. loc. 'saxicola', F. Bailey 287, no date; holo BRI.

Gymnographa medusulina Müll. Arg.

(Müller 1887: 62).

Sarcographa medusula Fée [Sarcographa medusula (Spreng.) Fée]

(Krempelhuber 1880: 341).

Glyphis medusulina Nyl. (sensu Shirley 1889)

(Shirley 1889: 214)

Type: Queensland: Rockhampton, A.Thozet s.n., no date; holo G. 
Thallus fawn to pale fawn, 1-2 mm thick, saxicolous, surface smooth and dull (superficially resembling fine velvet); apothecia lirelliform, inconspicuous, black, numerous, open, straight, curved or sinuous, often branched and in sub-stellate clusters, immersed, individual lirellae $0.5-2 \mathrm{~mm}$ long, $0.1-0.2 \mathrm{~mm}$ wide, lacking a thalline margin; proper exciple absent; hymenium (100-)125-175(-200) $\mu \mathrm{m}$ tall; ascospores 8 per ascus, 2-3-seriate, rounded ellipsoid, pale brown, $12-15 \mu \mathrm{m}$ long, $5-7 \mu \mathrm{m}$ wide, 4-locular.

Chemistry: no lichen compounds found.

Distribution: endemic; known only from eastern Queensland where it occurs on basalt and sandstone.

Notes: Phaeographis eludens is characterised by the substrate preference, the smooth, thick thallus, the small, 4-locular ascospores and by the absence of lichen compounds.

In 1880 Krempelhuber published one of the earliest accounts of Australian lichens in which he described 122 species, including several new species. (Krempelhunber 1880). The species reported included a saxicolous specimen of 'Sarcographa medusula Fée', species number 120, sent to him by Ferdinand v. Mueller. This specimen was later chosen by Müller (Müll. Arg.) as the type specimen for his new genus Gymnographa (Müller 1887). He referred to Krempelhuber's specimen as 'Sarcographa medusulina' [sic] but quoted Krempelhuber's publication and species number. Müller compared his new genus to Phaeographis but distinguished Gymnographa from the latter by the presence of dark cell walls, and the absence of lenticular locules, in the ascospores of his new genus.

Müller's report was included in Shirley's Lichen Flora of Queensland (Shirley 1889) but under the name 'Glyphis medusulina Nyl.' However, the syntypes of Glyphis medusulina Nyl. (H-NYL 7134, 7136, 7638, 6168 pm) [= Sarcographa medusulina (Nyl.) Müll. Arg.] are corticolous. All three reports (i.e. those of Krempelhuber, Müller and Shirley) refer to the same saxicolous specimen from Rockhampton, collected by A. Thozet.

The descriptions of the specimen by Krempelhuber, Müller and Shirley, in particular that of the smooth saxicolous thallus, the immersed, stellate branched lirellae and the small, brown 4-locular ascospores, all show that the specimen is Phaeographis eludens (Stirt.) Shirley (Stirton 1881; Shirley 1889; Archer 2000). This is confirmed by a comparison of Thozet's specimen (from G) with recent collections of P. eludens, in particular, the two specimens (Streimann 52358 \& 52630A, cited below) recently determined as Gymnographa medusulina (Sipman 1998).

The only reported difference between P. eludens and G. medusulina is the shape of the ascospore locules and the colour of the ascospore walls. Ascospores in the genus Phaeographis are known to become dark brown and distorted with age and the specimen seen by Krempelhuber and Müller is an old specimen of Phaeographis eludens with dark, distorted ascospores.

Specimens examined: Queensland: Isla Gorge National Park, $27 \mathrm{~km}$ NNE of Taroom, on sandstone rocks, Streimann 52630A, Aug 1993 (B, CANB); Mt Archer Environmental Park, 7 km NE of Rockhampton, Streimann 52358, Aug 1993 (B, CANB).

Phaeographis exaltata (Mont. \& Bosch) Müll. Arg. (Fig. 1c, 2d)

(Müller 1882a: 336).

Lecanactis exaltata Mont. \& Bosch

(Montagne \& van den Bosch 1855: 475).

Type: Indonesia. Java. s. loc., F.W. Junghuhn s.n., no date; lecto L (Wirth \& Hale 1978: 27). 
Phaeographis benguetensis (Vain.) Zahlbr.

(Zahlbruckner 1923: 365).

Graphis benguetensis Vain.

(Vainio 1920: 222).

Type: The Philippines: Luzon, Benguet: Pauai, E.D. Merrill 6648, May 1909; holo TURV 27426

Thallus pale fawn, thin, corticolous, surface smooth and slightly shiny; apothecia initially fissurine, becoming lirelliform, conspicuous, black, scattered, open, straight, curved or sinuous, rarely branched, immersed to subsessile, $1-5 \mathrm{~mm}$ long, $0.3-0.5 \mathrm{~mm}$ wide, with a variably conspicuous raised thalline margin; proper exciple completely carbonised, with a thick base and thin sides; hymenium 100-150(-200) $\mu \mathrm{m}$ tall; epithecium black, faint white pruinose; ascospores 8 per ascus, 2-seriate, pale brown, (21-)25-31(-33) $\mu \mathrm{m}$ long, (7-)8-10(-11) $\mu \mathrm{m}$ wide, 6-locular.

Chemistry: no lichen compounds found (Wirth \& Hale, 1978).

Distribution: occurs in Mexico, Dominica, Brazil, Japan, New Zealand, Hawaii, Sabah, India, the Philippines, Indonesia, Papua New Guinea, New Caledonia and New Zealand; in Australia it is found in Queensland, New South Wales, Victoria, and Tasmania where it is a common species.

Reported substrates in Australia include Banksia, Doryphora, Elaeocarpus and Nothofagus.

Notes: Phaeographis exaltata is characterised by conspicious black apothecia with thalline margins, 6-locular ascospores and the absence of lichen compounds. It is distinguished from Phaeographis dendroides (possessing a similar proper exciple to that of $P$. exaltata ) by the absence of stictic acid.

Wirth and Hale (1963) described a specimen of P. exaltata from Mexico which contained an unidentified lichen acid, identical to that present in Graphina virginea (Eschw.) Müll. Arg.; this compound was later reported to be hypostictic acid (Harris 1995). Similar specimens were described from Dominica and elsewhere by Wirth and Hale (1978) who reported that the majority of the Palaeotropic specimens contained no lichen acids but that the majority of the Neotropic specimens contained the unknown acid (hypostictic acid). These results suggest that Palaeotropic specimens are P. exaltata (lacking lichen compounds) and Neotropic specimens are P. necopinata A.W. Archer \& Elix (Archer \& Elix 1999), which contains hypostictic acid. P. necopinata appears less frequent in Australia than P. exaltata.

Specimens examined: Queensland: Wooroonooran National Park, margin of montane rainforest, Lumbsch 11113h, Jul 1996 (herb. Lumbsch).

New South Wales: Allyn Forest Park, Burraga Swamp, Kantvilas 195/88, Jun 1988 (HO, NSW 231673); New England National Park, 3 km W of Point Lookout, Kantvilas 657/88, Aug 1988 (HO, NSW 219597); ibid., Weeping Rock Track, 72 km E of Armidale, Elix 33897, Aug 1993 (CANB); Barrington Tops National Park, Kantvilas 444/88, Jul 1988 (NSW 231133); ibid., 42 km WNW of Gloucester, Streimann 44515, May 1990 (CANB); Stewarts Brook State Forest, Barrington Tops Forest Rd, Lumbsch 86780, Jun 1991 (herb. Lumbsch); Brown Mountain, 17 km SE of Nimmitabel, Elix 9654, Feb 1982 (CANB).

Victoria: Coast Range Road, 18 km SSE of Bendoc, Elix 19988, Apr 1986 (CANB).

Tasmania: Mount Victoria Track, Kantvilas 523/80, Nov 1980 (HO); Arthur River, N of Waratah, Kantvilas 9/82, Jan 1982 (HO); Mount Dundas Track, Kantvilas 546/88, Dec 1988 (HO). 
Phaeographis hypoglaucoides K.P. Singh \& Awasthi (Fig. 1d, 2e)

(Singh \& Awasthi 1979: 109).

Type: India. Palni Hills on way to Thandikuddi, alt. 1350 m, D.D. Awasti \& K.P. Singh 70.459, no date; holo LWU.

Thallus yellowish brown, $0.4-0.6 \mathrm{~mm}$ thick, saxicolous, surface smooth and dull; apothecia lirelliform, conspicuous, black, scattered, open, immersed, 0.1-0.3 mm wide, forming clusters of repeatedly branched lirellae, 1-2.5 mm wide; proper exciple very pale brown, uncarbonised, inconspicuous; hymenium 80-100 $\mu \mathrm{m}$ tall; epithecium dull, epruinose; ascospores 8 per ascus, irregularly 1-seriate, pale brown, ellipsoid, $12-15 \mu \mathrm{m}$ long, 5-6 $\mu \mathrm{m}$ wide, 4-locular.

Chemistry: no lichen compounds found.

Distribution: occurs in India, and in Australia, in Queensland.

Notes: Phaeographis hypoglaucoides is characterised by the substrate preference, the conspicuous, black, open lirellae (resembling those of $P$. ceratoides ), the small 4-locular acospores and the absence of lichen compounds. It is distinguished from the two other saxicolus Phaeographis species found in Australia viz: P. eludens and P. tuberculifera A.W. Archer, by the conspicuous, black open lirellae.

Specimen examined: Queensland: Mount Archer Environmental Park, 7 km NE of Rockhampton, on semi-shaded boulder, Elix 34516, Aug 1992 (CANB).

Phaeographis melanostalazans (Leight.) Müll. Arg. (Fig. 1e, 2f)

(Müller 1882a: 336).

Platygrapha melanostalazans Leight.

(Leighton 1869: 180).

Type: Ceylon [Sri Lanka]: South of the Island, G. Thwaites 155, no date; lecto BM (Singh \& Awasthi 1979: 102).

Phaeographis hypomelaena Müll. Arg.

(Müller 1886: 313)

Type: French Guyana, s. loc., F.R. Leprieur 188, no date (holo G , fide Kalb 2001: 150).

Thallus pale fawn, thin, corticolous, surface smooth and shiny (chondroid); apothecia lirelliform, black, conspicuous, scattered, numerous, open, straight, curved or sinuous, sometimes branched, immersed, $1-5 \mathrm{~mm}$ long, $0.2-0.3 \mathrm{~mm}$ wide, with a thin thalline margin; proper exciple completely carbonised, thick, wide at the base, tapering upwards; hymenium 100-120 $\mu \mathrm{m}$ tall; epithecium black, fine white pruinose; ascospores 8 per ascus, pale brown, ellipsoid, 25-37 $\mu \mathrm{m}$ long, 8-10 $\mu \mathrm{m}$ wide, $8-9$ locular.

Chemistry: stictic acid.

Distribution: occurs in India, Sri Lanka, Indonesia, French Guyana, Mexico, Hawaii and, in Australia, in Queensland.

Notes: Phaeographis melanostalazans is characterised by the 8-9 locular ascospores, the thick tapering base of the proper exciple and the presence of stictic acid. Redinger (1936) reports slightly smaller ascospores 25-32 $\mu \mathrm{m}$ long, 6-8 $\mu \mathrm{m}$ wide, cf. 25-37 $\mu \mathrm{m}$ long, 8-10 $\mu \mathrm{m}$ wide.

Singh and Awasthi (1979) report the the ascospores to be 8-10 locular, similar to those seen in the type material; in the Australian specimens examined, the ascospores were 
predominantly 9 locular but sometimes with a poorly defined terminal locule. Phaeographis hypomelaena Müll. Arg. was recently reported from Australia (Kalb 2001). This species has a carbonised proper exciple tapering from the base (cf. Kalb. op. cit., Fig. 7, p. 151), ascospores 20-38 × 7-11 $\mu \mathrm{m}, 6-11$ locular and contains stictic acid; it is here reported as a later synonym of $P$. melanostalazans.

The Japanese species Phaeographis yakushimensis Nakanishi (Nakanishi 1966) resembles P. melanostalazans but the ascospores in the Japanese species are 35-42 $\mu \mathrm{m}$ long and the species lacks lichen compounds.

Specimens examined: Queensland: Black Mountain Road, 16 km NW of Kuranda, Streimann 31153, Jul 1984 (CANB, US); Christmas Pocket, 16 km W of Kuranda, Elix 17564, 17581, Jul 1984 (CANB).

Phaeographis mucronata (Stirt.) Zahlbr. (Fig. 3a)

(Zahlbruckner 1923: 382)

Graphis mucronata Stirt.

(Stirton 1876: 95)

Type: Australia: New South Wales: Riverina District, H. Paton s.n., 1875; lecto BM (Rogers 1982: 504).

Phaeographis australiensis Müll. Arg.

(Müller 1882b: 504)

Type: Australia: New South Wales: Parramatta, W. Woolls s.n., no date; lecto G (Archer 2000:463).

Additional synonyms have been reported previously (Archer 2000).

Phaeographis mucronata is illustrated, described and discussed (as P. australiensis Mull. Arg.) elsewhere (Archer 2000).

Distribution: Phaeographis mucronata (as P. australiensis) was reported to be a common species in eastern Australia (Archer 2000). Additional specimens have been seen from Tasmania, Bass Strait (where the species occurs on most of the islands including Flinders Island, Clarke Island, Dover Island, Erith Island, Deal Island, Litle Green Island, Babel Island, and West Sister Island) and Western Australia. Phaeographis mucronata is thus, so far, the most widely distributed species in the Australian Graphidaceae. Additional substrates reported are Acacia, Bossia, Callitris, Dodonea, Leucopogon, Pinus, Pomaderris and Spyridium.

Notes: Phaeographis mucronata was previously reported as a Phaeographis species of uncertain status (Archer 2000) as the type was not then available for examination. The type has now been seen and found to be identical to $P$. australiensis Müll. Arg. The structure of the lirellae and the ascospores are identical in both species, in particlar, the ascospores are often terminally acute, as illustrated by Stirton (in sched.); cf. Hayward 1977: 574, Fig. 7, 1a; Archer 2000: 464. Fig. 1a.

Specimens examined: Tasmania: Bass Strait, West Sister island, Whinray s.n., Dec 1966 (MEL 27978); ibid., Clarke island, Whinray 1397, Nov 1979 (MEL); ibid., Flinders Island, Whinray 1715, Jun 1986 (MEL).

Western Australia: 22 km W of Manjimup, Macfarlane 2059(3), Oct 1992 (MEL); The Cascades, 4 km S of Pemberton, Elix 41102, Sep 1994 (CANB); Mt. Chudalup, 17 km SSE of Northcliffe, Elix 41177, Sep 1994 (CANB). 


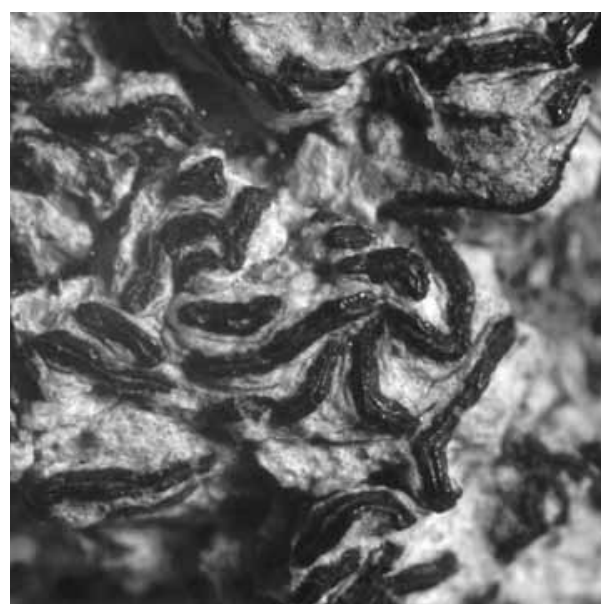

a

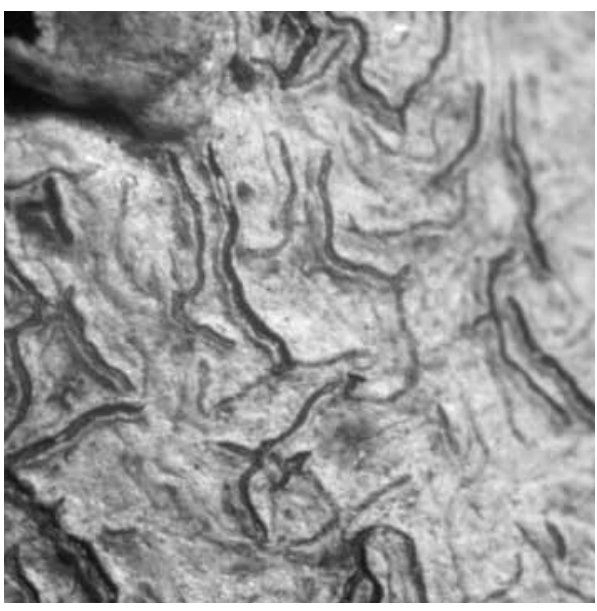

C

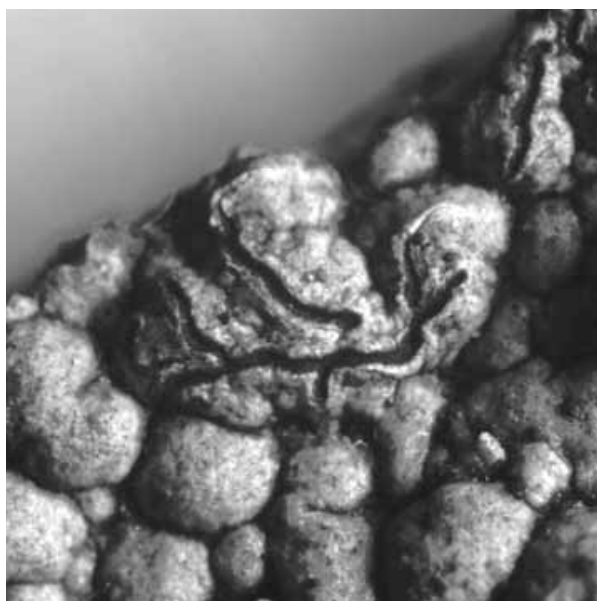

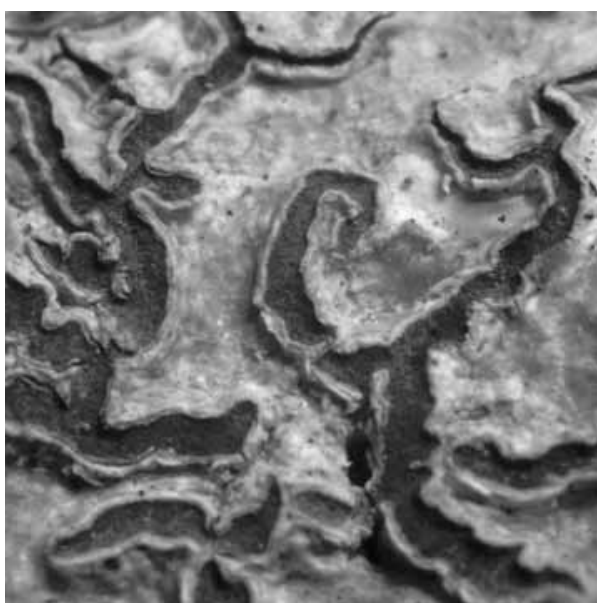

b

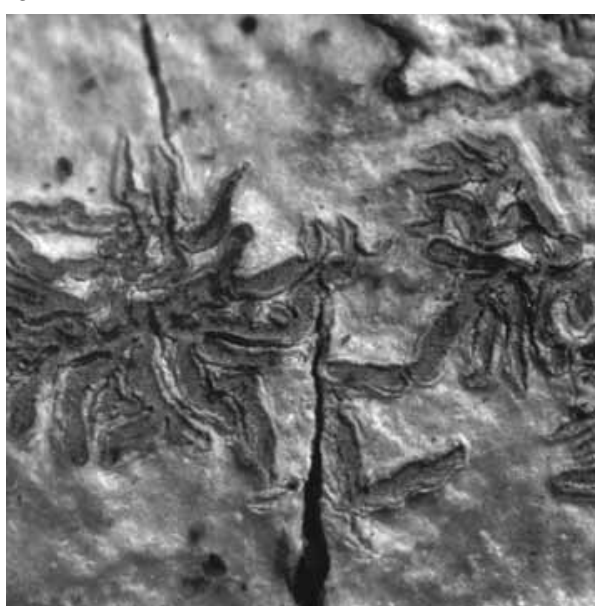

d

Fig. 3. a, Phaeographis mucronata (Stirt.) Zahlbr., holotype (BM); b, Phaeographis nardiensis A.W. Archer, holotype (NSW 456279); c, Phaeographis subdividens (Leight.) Müll. Arg., lectotype (BM); d, Phaeographis subtigrina (Vain.) Zahlbr., Archer G 24 (NSW 441963); e, Phaeographis tuberculifera A.W. Archer, holotype (CANB). All $\times 17$. 
Phaeographis nardiensis A.W. Archer, sp. nov. (Fig. 1f, 3b)

Phaeographis dendritica similis sed ascosporiis minoribus et excipulo deficienti differt.

Type: Australia: New South Wales: Mount Nardi, c. 28 km N of Lismore, alt. 800 m, on fallen branch, A.W. Archer G 285, 4.xi.1998 (holo NSW 456279).

Thalus pale fawn, thin, corticolous, surface smooth and shiny; apothecia lirelliform, conspicuous, black, open, $0.25-0.5 \mathrm{~mm}$ wide, with a conspicuous thalline margin, subsessile to sessile, in clusters of intricately branched lirellae, clusters $2-5 \mathrm{~mm}$ diam, lirellae; proper exciple lacking; hymenium 125-175 $\mu \mathrm{m}$ tall; epithecium black, fine white pruinose; ascospores 8 per ascus, irregularly 2-seriate, pale brown, 28-36 $\mu \mathrm{m}$ long, 7-9 $\mu \mathrm{m}$ wide, 6-8 locular.

Chemistry: norstictic acid.

Distribution: endemic; occurs in Queensland and northern New South Wales.

Notes: Phaeographis nardiensis is characterised by the clustered, branched lirellae, the absence of a proper exciple and the presence of norstictic acid. The species is distinguished from the chemically similar P. dendritica (Ach). Müll. Arg. by the smaller ascospores (28-36 × 7-9 $\mu \mathrm{m}, \mathrm{cf} .30-50 \times 7-10 \mu \mathrm{m})$ and the absence of a well-defined proper exciple.

Phaeographis nardiensis resembles $P$. exaltata but is distinguished from that species by the absence of a proper exciple and the presence of norstictic acid.

Specimens examined: Queensland: Tully Falls Road, 8 km SE of Ravenshoe, Elix 16818, Jun 1984 (CANB).

New South Wales: type locality, Archer G 310, Nov 1998 (NSW 458523); Dorrigo National Park, The Glade, Archer G 511, Oct 2000 (NSW 456277); ibid., track to Tristania Falls, Archer G 599, Nov 2000 (NSW 456278).

Phaeographis subdividens (Leight.) Müll. Arg. (Fig. 1g, 3c)

(Müller 1882a: 383).

Graphis subdividens Leight.

(Leighton 1869: 177).

Type: Ceylon [Sri Lanka]: Central Province, G. Thwaites s.n., (Leighton CL 147), no date; lecto BM (Singh \& Awasthi 1979: 108).

Thallus off-white to pale fawn, thin, corticolous, surface smooth and shiny; apothecia lirelliform, numerous, scattered, black, open, semi-immersed, simple or rarely branched, straight, curved or sinuous, $1-3 \mathrm{~mm}$ long, $0.15-0.25 \mathrm{~mm}$ wide; proper exciple brown to dark brown, lateral, yellow brown below; epithecium black, epruinose; hymenium $80-100 \mu \mathrm{m}$ tall; ascospores 8 per ascus, irregularly 2-seriate, rounded ellipsoid, pale brown, (16-)18-22 $\mu \mathrm{m}$ long, 6-8 $\mu \mathrm{m}$ wide, 4-6 locular.

Chemistry: no lichen compounds found.

Distribution: occurs in India, Sri Lanka and, in Australia, northern Queensland. The only reported substrate in Australia is Dysoxylum.

Notes: Phaeographis subdividens is characterised by the black, open lirellae, the brown, lateral proper exciple and by the absence of lichen compounds. The brown proper exciple distinguishes the species from all other Phaeographis species found in Australia as these either lack a proper exciple or possess a carbonised proper exciple. The ascospores in the Indian specimens examined by Singh and Awasthi (1979) were reported to be 16-22 × 5-7 $\mu \mathrm{m}$ and 5-6 locular. 
Specimens examined: Queensland: Forrest Beach, 16 km SE of Ingham, Elix 15936, Jun 1984 (CANB); Gordon Creek, 19 km SW of Cape Weymouth, Streimann 56571, Oct 1995 (B, CANB).

Phaeographis subtigrina (Vain.) Zahlbr. (Fig. 1h, 3d)

(Zahlbruckner 1923: 287).

Graphis subtigrina Vain.

(Vainio 1907: 177).

Type: Thailand: Koh Chang: Lem Dan, J. Schmidt XXI, 1900; lecto TUR-V 27501 (Wirth \& Hale 1978: 29).

Thallus pale fawn, thin, corticolous, surface smooth and slightly shiny; apothecia lirelliform, inconspicuous, black, open, simple or branched, straight or curved, or in substellate clusters, immersed to subsessile, the lirellae $0.5-1.5 \mathrm{~mm}$ long, $0.15-0.3 \mathrm{~mm}$ wide, with a conspicuous thalline margin, lacking a proper exciple; epithecium black, white pruinose; hymenium $80-100 \mu \mathrm{m}$ tall; ascospores 8 per ascus, pale brown, ellipsoid, 15-22(-25) $\mu \mathrm{m}$ long, 6-9 $\mu \mathrm{m}$ wide, 4-locular.

Chemistry: norstictic acid.

Distribution: occurs in Thailand, India, the Philippines, Dominica, the USA (Florida) and, in Australia, in Queensland and New South Wales. The only reported substrate in Australia is Acacia.

Notes: Phaeographis subtigrina is characterised by the open lirellae in substellate clusters, the 4-locular ascospores and by the presence of norstictic acid. The species is inconspicuous and easily overlooked. The ascospores in the Australian specimens are similar in size to those reported from India [15-18(-20) $\times 9-10 \mu \mathrm{m}$, Singh \& Awasthi (1979)].

All of the Australian specimens examined contained norstictic acid but specimens from Florida may contain norstictic acid, with or without stictic acid or lack lichen compounds altogether (Harris 1995).

Specimens examined: Queensland: Giangurra, 6 km E of Cairns, Lumbsch 11141a, Jul 1996 (herb. Lumbsch); Brisbane, Enoggara Dam, Stevens s.n., Nov. 1999 (herb. Stevens).

New South Wales: Bouddi National Park, Elix 4663, May 1978 (CANB); track to Dangar Falls, c. 2 km N of Dorrigo, Archer G 316, Oct 1998 (NSW 441971); Thornleigh, track by side of Berowra Creek, Archer G24, Dec 1997 (NSW 441963); Cumberland State Forest, c. 25 km NW of Sydney, Archer G443, Apr 2000 (NSW 440786); Dharug National Park, c. 50 km NNW of Sydney, Archer G 444, Apr .2000 (NSW 440800); Cheltenham, Pennant Hills Park, c. 20 km NW of Sydney, on tree by side of Devlins Creek, Archer G448, May 2000 (NSW 440808).

Phaeographis tuberculifera A.W. Archer, sp. nov. (Fig. 1i, 3e)

Phaeographis eludens similis sed thallo tuberculato et lirellis thallinovestitis differt.

Type: Australia: Queensland: Tozers Gap, Iron Range National Park, 29 km SW of Cape Weymouth $\left(12^{\circ} 44^{\prime} \mathrm{S}, 143^{\circ} 11^{\prime} \mathrm{E}\right)$, alt. $120 \mathrm{~m}$, on semi-exposed sloping boulder, H. Streimann 56404, 12.x.1995 (holo CANB).

Thallus pale greenish brown, $0.5-2 \mathrm{~mm}$ thick, saxicolous, conspicuously tuberculate, surface smooth and dull; apothecia lirelliform, inconspicuous, black, scattered, immersed, slightly open, straight, curved, sinuous or branched, 1-2 mm long, $0.05-0.1 \mathrm{~mm}$ wide; with a thin white thalline margin; proper exciple lacking; hymenium 100-120 $\mu \mathrm{m}$ tall; ascospores 8 per ascus, 1-seriate, rounded cylindrical, pale brown, 10-12 $\mu \mathrm{m}$ long, 4-5 $\mu \mathrm{m}$ wide, 4-locular. 
Chemistry: no compounds found.

Distribution: endemic; known only from northern Queensland.

Notes: Phaeographis tuberculifera is characterised by the tuberculate thallus, immersed black lirellae with a thin white thalline margin, 4-locular ascospores and by the absence of lichen compounds. The other Australian saxicolous Phaeographis species, $P$. eludens and P. hypoglaucoides are distinguished from P. tuberculifera by the larger ascospores and a continuous rather than a tuberculate thallus.

\section{Excluded species}

Phaeographis malacodes (Nyl.) Zahlbr.

(Zahlbruckner 1923: 381).

Graphis malacodes Nyl.

(Nylander 1868: 77).

Type: New Caledonia: Lifu: Thiébaut s.n., 1864 (holo H-NYL 7681).

The ascospores in Graphis malacodes are hyaline and the species is therefore correctly placed in the genus Graphis. The transfer to Phaeographis is unneccessary (Archer 2001b).

Phaeographis subinusta (Leight.) Müll. Arg.

(Müller 1882a: 382).

Graphis subinusta Leight.

(Leighton 1869: 177).

Type: Ceylon (Sri Lanka): Peradeniya: G. Thwaites s.n., (Leighton CL 160), no date; lecto BM (Singh \& Awasthi 1979: 101).

Phaeographis subinusta is characterised by the completely carbonised proper exciple, the large, multilocular ascospores (30-45 $\times 10-12 \mu \mathrm{m}, 8-11$ locular) and by the presence of norstictic acid (in the lectotype, fide K.Kalb in litt.).

The species is reported from New South Wales (Filson 1996: 103) but no specimens corresponding to $P$. subinusta have yet been seen among the Australian Phaeographis specimens examined.

\section{Acknowledgments}

The author is grateful to the Herbaria cited above for the loan of type and other specimens and to the National Herbarium of New South Wales for funding provided through the New South Wales Diversity Strategy, for permission to use the facilities of the Herbarium and for arranging the loan of type and other specimens, and to Ms. L. Elkan (NSW) for the drawings.

\section{References}

Archer, A.W. (1999) The lichen genera Graphis and Graphina (Graphidaceae) in Australia 1: Species based on Australian type specimens. Telopea 8: 273-295. 
Archer, A.W. (2000) The lichen genera Phaeographis and Phaeographina (Graphidaceae) in Australia 1: Species based on Australian type specimens. Telopea 8(4): 461-475.

Archer, A.W. (2001a) The lichen genera Phaeographis and Phaeographina (Graphidaceae) in Australia 2: Phaeographina - new reports and new species. Telopea 9(2): 329-344.

Archer, A.W. (2001b) The lichen genus Graphis (Graphidaceae) in Australia. Australian Systematic Botany 14: 245-271.

Archer, A.W. (2001c) Phaeographina elixii, a new species of Graphidaceae from Australia. Bibliotheca Lichenologica 78; 13-16.

Archer, A.W. \& Elix, J.A. (1999) Three new species in the Australian Graphidaceae with novel chemistries: Phaeographina echinocarpica, Phaeographis necopinata and Pheographis nornotatica. Mycotaxon 72: 91-96.

Coppins, B.J. \& James, P.W. (1992) Phaeographis in Purvis, O.W. et al. (Eds) The Lichen Flora of Great Britain and Ireland. (Natural History Publications: London).

Filson, R.B. (1996) Checklist of Australian lichens and allied fungi. Flora of Australia Supplementary Series Number 7. (Australian Biological Resources Study: Canberra).

Harris, R.C. (1995) More Florida Lichens. (New York Botanical Gardens: New York).

Hayward, G.C. (1977) Taxonomy of the lichen families Graphidaceae and Opegraphaceae in New Zealand. New Zealand Journal of Botany 15: 565-584.

Kalb, K. (2001) New or otherwise interesting lichens. Bibliotheca Lichenologica 78: 141-167.

Krempelhuber, A. (1880) Ein neuer Beitrag zur Flechten-Flora Australiens. Verhandlung der Kaiserlich-Königlichen Zoologisch-Botanischen Gesellschaft in Wien 30: 392-342.

Leighton, W.A. (1869) The Lichens of Ceylon. Transactions of the Linnean Society of London 27: 161-185.

Montagne, C. \& Bosch, van den R.B. (1855) Lichenes in Miquel, F.A.W.(Ed.) Plantae junghuhnianae. Part 4: 395-522 (J.B. Ballière: Paris).

Müller, J. (1882a) Lichenologische Beiträge XV. Flora 65: 326-337; 381-386.

Müller, J. (1882b) Lichenologische Beiträge XVI. Flora 65: 483-490; 499-505.

Müller, J. (1886) Lichenologische Beiträge XXIV. Flora 69: 307-318.

Müller, J. (1887) Lichenologische Beiträge XXV. Flora 70: 56-64.

Müller, J. (1891) Lichenes Bellendenici. Hedwigea 30: 47-56.

Nakanishi, M. (1966). Taxonomical Studies on the Family Graphidaceae of Japan. Journal of Science of the Hiroshima University, series B, Division 2 (Botany): 11: 51-126.

Nylander, W. (1868) Synopsis Lichenum Novae Caledoniae. (Le Blanc-Hardel: Caen).

Redinger, K.M. (1936) Die Graphideen der Sunda-Inseln. Revue Bryologique et Lichénologique 9: 37-122.

Rogers, R.W. (1982) Typification of the species of lichens described from Australian specimens by James Stirton. Austrobaileya 1: 502-510.

Shirley, J. (1889) The lichen Flora of Queensland. Proceedings of the Royal Society of Queensland 6: 165-218.

Singh, K.P. \& Awasthi, D.D. (1979). Lichen genus Phaeographis from India. Bulletin of the Botanical Survey of India 21: 97-120.

Sipman, H. (1998) Additional lichen records from Australia 34. Australasian Lichenology 42: 10-11.

Stirton, J. (1876) Lichens British and Foreign. Transactions of the Glasgow Field Naturalists 4: 85-95.

Stirton, J. (1881) Additions to the Lichen Flora of Queensland. Transactions and Procedings of the Royal Society of Victoria 17: 66-78.

Vainio, E.A. (1907) Lichenes novi rarioresque. Ser. IV. Hedwigia 46: 168-181.

Vainio, E.A. (1920) Lichenes insularum Philippinarum III. Annales Academiae Scientiarum Fennicae, Series A. 15 (6): 1-368.

Wirth, M. \& Hale, M.E. (1963) The lichen family Graphidaceae in Mexico. Contributions from the United States National Herbarium 36 (3): 63-119.

Wirth, M. \& Hale M.E. (1978) Morden-Smithsonian Expedition to Dominica: The Lichens (Graphidaceae). Smithsonian Contributions to Botany. No. 40: 1-64.

Zahlbruckner, A. (1923) Catalogus lichenum universalis, vol. 2. (Borntraeger: Leipzig).

Manuscript received 10 January 2001

Manuscript accepted 28 September 2001 